тим вище В33. На нашу думку підвищення В33 води, було доцільно провести мікробіологічні відбулося через зміщення рН в лужну сторону. За дослідження зразків. Дослідження проведені на рахунок активації молекул води відбувається предмет загального бактеріального обсіменіння. збільшення гідроксид-іонів (OH-), вони 3 більшою Для дослідження були взяті зразки із внесеними $\begin{array}{rlllr}\text { швидкістю приєднуються до вільних групам } & \text { фракціями електроактивованої } & \text { води } & \text { у } \\ \text { білкової молекули, тому займають більшу кількість } & \text { співвідношеннях католіт/аноліт 10/90; 50/50; 90/10. }\end{array}$

$\begin{array}{lll}\text { білкової молекули, тому займають більшу кількість } & \text { співвідношеннях католіт/аноліт 10/90; 50/50; 90/10. } \\ \text { позитивних іонів, а оте підвищують } & \text { Отримані результати представлені на рисунку } 3 .\end{array}$ вологозв'язуючу здатність фаршу. 3 цього можна зробити висновок про можливість підвищенн вологозв'язуючої здатності м'яса без використанни фосфатних добавок.

Вихід готового продукту $є$ головним показник напряму затежить від вологозв' язуючо здатності м'ясної сировини. Ураховуючи те, шо у дослідних зразках значно пілвишився рівень вологозв'язуючої здатності доцільно було дослідити втрати при термообробщі модельного фаршу. Результати цього дослідження представлен на рисунку 2 .

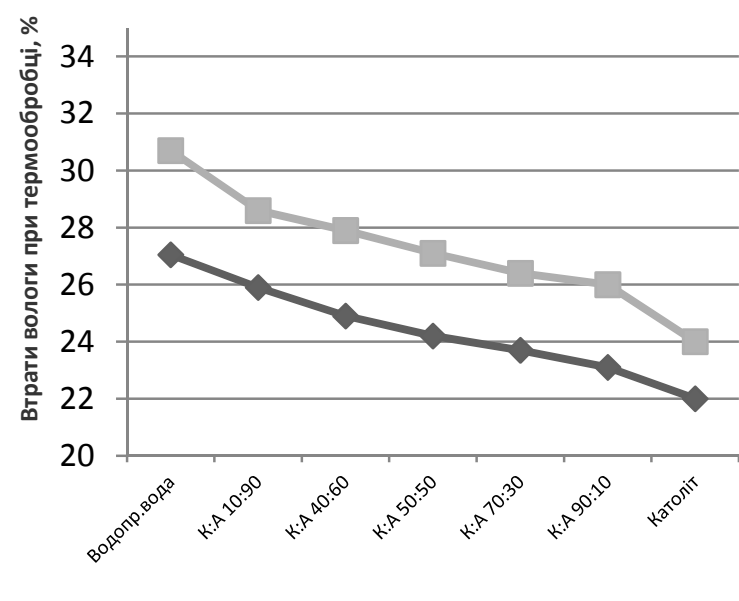

$\rightarrow$ Стегновий м'яз $\multimap-$ Найдовший м'яз

Рис.2. Вплив фракцій електроактивованої води на втрати вологи при термообробці модельного фаршу із свинини.

3 графіка видно, що без внесення будь-яких функціональних добавок (фосфатів, крохмалю тощо) можливо зменшити втрати вологи при термообробці навіть при використанні м'яса низьким $\mathrm{pH}$ (PSE). В залежності від співвідношення фракцій електроактивованої води можливо підвищити вихід до $8 \%$. Це можна пояснити Тим, що утворені зв 'язки білків м' язово тканини 3 активними молекулами води набагато

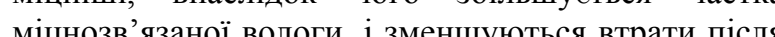
термічної обробки. У зв'язку з ная

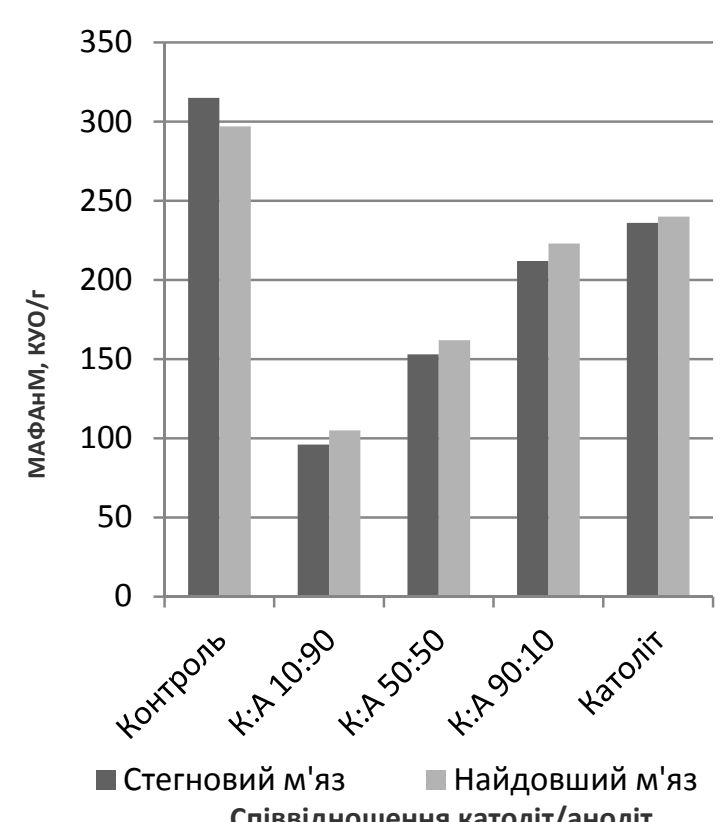

Співвідношення католіт/аноліт

Рис.3. Вплив етектроактивованої води на мікробіологічні показники зразків модельного фаршу із свинини з пороками автолізу

Згідно СанПін 2.3.2.1078-01 загальна бактеріальна забрудненість сирого фаршу не повинна перевищувати межу в $5 \times 10^{6}$ колоній. Як видно 3 графіка, жоден зразок не перавищує допсстимих норм замен тенденція зміни бактеріального обсіменіння залежно від співвідношення кислоі 1 лужної що контрольний зразок з питною водопровідною водою схильний більш активному розвитку
мікрофлори в порівнянні 3 зразками 3 Остаточні рего водог.

О人 використанню проволили на основі впиву електроактивованої зразків ковбас. Органолептична оцінка дослідних зразків за 9-ти баловою шкалою згідно 3 ГОСТ 9959-91 «Продукты мясные. Общие условия проведения органолептической оценки». Оцінку проводили у дослідних зразках варених ковбас із свинини. Результат представлений у таблиці 1. фракцій води, внесеної в зразки. Також помітно, води на органолептичні показники дослідних

Табллия 1 - Балова органолептична оцінка дослідних зразків варених ковбас із свинини.

\begin{tabular}{|c|c|c|c|c|c|c|c|}
\hline \multirow[b]{2}{*}{ Зразки } & \multicolumn{6}{|c|}{ Показники } & \multirow[b]{2}{*}{ Загальна оцінка } \\
\hline & $\begin{array}{c}\text { Зовнішній } \\
\text { вигляд }\end{array}$ & $\begin{array}{l}\text { Колір на } \\
\text { розрізі }\end{array}$ & Аромат & Смак & Консистенція & Соковитість & \\
\hline Контроль & $\frac{6}{6}$ & $\frac{1030131}{6}$ & 7 & 6 & 4 & 4 & 5,5 \\
\hline Католіт 100\% & 9 & 7 & 3 & 3 & 8 & 9 & 6,5 \\
\hline $\mathrm{K}: \mathrm{A}=90: 10$ & 9 & 7 & 4 & 4 & 8 & 9 & 6,8 \\
\hline $\mathrm{K}: \mathrm{A}=70: 30$ & 9 & 8 & 8 & 8 & 8 & 9 & 8,3 \\
\hline $\mathrm{K}: \mathrm{A}=50: 50$ & 9 & 8 & 9 & 9 & 9 & 9 & 8,8 \\
\hline $\mathrm{K}: \mathrm{A}=30: 70$ & 8 & 9 & 8 & 9 & 8 & 8 & 8,3 \\
\hline $\mathrm{K}: \mathrm{A}=10: 90$ & 8 & 9 & 4 & 4 & 7 & 7 & 6,5 \\
\hline
\end{tabular}

Висновки

Підсумувавши результати досліджень, можна відзначити, що внесення електроактивованої води сприятливо впливає на функціонально-технологічні властивості модельного фаршу. Саме за допомогою фракцій електроактивованоі води можливе спрямоване регулювання рН м'ясних систем, підвищення волого 'Азюо здатності на 20 $22 \%$, скорочення втрат вологи при термообробці до $8 \%$. Данні органолептичноі оцінки дали можливість рекомендувати оптимальні
співвідношення фракцій електроактивованої води

для використання при виробництві м'ясних продуктів із свинини. Оптимальний діапазо (0:60дношень (католіт:аноліт) становить 60:40 рекомендованому діапазоні фракщій дас можливість корегувати функшіональнотехнологічні властивості свинини з ознаками PSE не погіршуючи органолептичні показники готового продукту. Також відзначено поліпшення мікробіологічних показників модельного фаршу, що в свою чергу дозволить подовжити терміни сідвідошення фракей

Список літератури:

Баранов В.И. Мясные гечества чистопородных и гибридных свиней/ В. И. Баранов// Зоотехния, 1996 - №3, - с.21-

2. Качество мяса и мясопродуктов / Ю. Ф. Заяс.// М.: Легкая и пищевая промышленность, $1981 .-480$ с.

3. Brown S. N. Meat quality in pigs subjected to minimal pre-slaughter stress. / S. N. Brown, , P. D. Warriss, G. R. Nute, J. E.

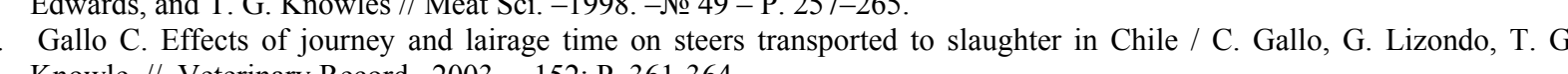
Forest J. 2010 Met Q

Download from http://ag.ansc.purdue.edu/meat_quality/meat quality problems.html on 11/06/2010.

6. Nanni Costa L.Combined effects of pre-slaughter treatments and lairage time on carcass and meat quality in pigs of differen halothane genotype. / L. Nanni Costa, D. P.Lo. Fiego, O. S. Dall, R. Davoli, V. Russo, // Meat Science -2002.- №61 - P - 4 Bowker B. C. Muscle metabolism and PSE pork. / B. C. Bowker, A. L. Grant, J. C. Forrest, and D. E. Gerrard /

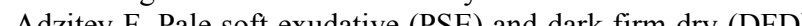

meats: causes and measures to reduce these incidences - a mini review. / F. Adzitey, H. Nurul // International Food Research Journal -2011 - №18.- P.11-20

9. Мясо с признаками PSE и DFD.[Електронний ресурс] - Режим доступу : http://meat-and-spices.com/myaso

10. Спиричев В.Б. Фосфор в рационе современного человека и возможные последствия не сбалансированного

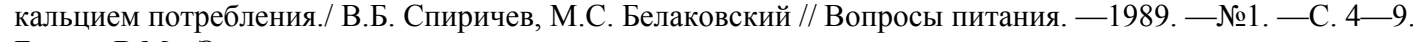

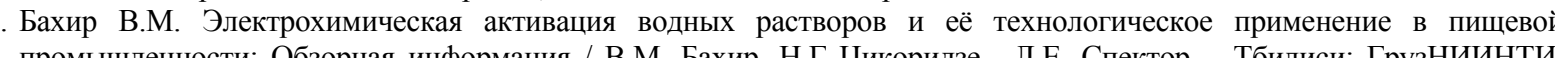

1988, вып. 3.- 80с

Control -2008 - № 19(4) -P.329-345

13. Пронькіна К.В. Корегування $\mathrm{pH}$ м'яса з ознаками PSE за допомогою електроактивованої води/К.В. Пронькін г. перспективи, ефек
Ч. 1. - С. $324-325$. 
УДК 637.344-027.3:613.2

\section{ОТРИМАННЯ МІКРОПАРТИКУЛЯТУ 3 КОНЦЕНТРАТУ БІЛКІВ МОЛОЧНОЇ СИРОВАТКИ}

Г. В. Дідух, кандидат технічних наук, доцент genad69@gmail.com: Кафедра технології ресторанного і оздоровчого харчування

Одеська національна академія харчових технологій
вул. Канатна, 112, м. Одеса, Україна, 65039

Анотація. У статті розглянуто проблему зниження калорійності харчових раціонів і представлено матеріали
наукових досліджень по доцільності використання модифікованого концентрату сироваткових білків у вигляді мікропартикуляту в якості імітатора жиру при виробництві кулінарної продукції. Розглянуто можливість отримання мікропартикуляту в умовах ресторанного господарства. Отримання мікропартикуляту досягається за умов сильного механічного зсуву на технологічному обладнанні - диспергаторі, при температурі вищій за температуру денатураціії органолептичні показники. Наведено реологічні властивості отриманого мікропартикуляту, а саме: вяязкість та та залежність швидкості деформегі від напруження зсуву. Цим доведено можливість використання рівняння Бінгама для розрахунку процесу плинності мікропартикуляту.

Ключові слова: мікропартикулят, білки, молочна сироватка, реологія, функціональне харчування

Аннотация. В статье рассмотрена проблема снижения калорийности пищевых рационов и представлены сывороточных белков в риде иикропртикулята в качестве имитатора жира при производстве кулинарной продукшии. Рассмотрена возможность получения микропартикулята в условиях ресторанного хозяйства. Получение микропартикулята достигается при условии сильного механического сдвига на технологическом оборудовании диспергаторе, при температуре выше температуры денатурации сывороточных белков. Определены функциональные свойства полученного продука, органолептические показатели. Приведены реологические свойства полученного икропартикулята, а именно: вязкость и зависимость скорости деформации от напряжения сдвига. Этим доказана Ключевые слова: микропартикулят, белки, молочная сыворотка, реология, функциональное питанис.

\section{Bступ}

До відмінних особливостей структури харчування населення розвинутих країн, у тому харчового рашіону. 3 урахуванням зниження фізичного навантаження населення, превалюс тенденція до малорухливого способу життя, збільшення частки розумової праці, проблема надлишкового споживання харчових нутрієнтів, зокрема жирів i вуглеводів, стає особливо актуальною. У відповідності 3 формулою збалансованого харчування середня добова потреб юдського організму в жирах складае 1 г на 1 к маси тіла людини, однак, аналіз макронутрієнтного статусу населення свідчить про перевищення цього Всесвітньої організації охорони здоров'я відзначається неухильне зростання чисельностї жжиінням, цукровим діабетом, серцевоУ зв'язгу з иим затача

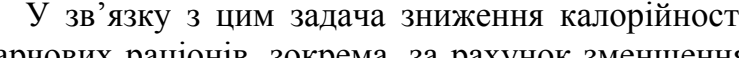

споживання жирів, $\epsilon$ актуальною. показника більше ніж у 2 рази. За даними о харчування на їі основі як біологічно повноцінні, 3 С̆ амінокислотним складом. Їх введення до складу продуктів стимулюе синтез білка в м'язах, що сприяе нарощуванню м'язової тканини і сили.

Деякі амінокислоти (особливо лейцин), які входять до складу сироваткових білків, при потраплянні в організм впливаюоь на гомеостаз тлюкози і мають інсулінотропну дію (стимулюють

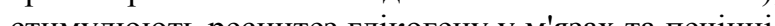
Це дуже важливо для реабіпітаиї організму. Споживання на ранній стадії реабілітачії напоїв, до або їнні гідролізати, сприяе відновленню м'язової тканини порівнянні зі споживанням напоїв тільки на вуглеводневій основі.

Сироваткові білки багаті цистеіном, тому вони $\epsilon$ ідеальним інгредієнтом при виробництві добавок та функціональних продуктів для підтримання печінки. Цистеїн є лімітованою амінокислотою, попередником глутатіону - потужного антиоксиданта, який знижує небажаний ефект радіаційного опромінення, онкологічної хіміотерапlи і токсинів, наприклад алкоголю. У якості нейтралізатора важких металів він сприяе віріграс важливу роль у попередкі захоров раку печінси; призупиняс процеси старіння.

Молочна сироватка і сироваткові білки $є$ також прекрасною сировиною або компонентом у складі рецептур при виробництві нових продуктів процес травлення, обмін речовин і вагу тіла. Це пов'язано 3 тим, що сироватка, $\epsilon$ високоякісним джерелом білка зі збалансованим амінокислотним складом, стимулює синтез лептину (гормону насичення). Гормон насичення, який синтезують клітини шлунково-кишкового тракту за умови кров і пригнічуе відчуття голоду. Таким чином, функціональні продукти, які містять сироваткові білки можливо використовувати людям 3 зайвою Когі

Крім того, встановлено, що гідролізати сироваткових білків містять велику кількість дію при гіпертонії, захворюваннях серцевосудинної системи. Компоненти, виділені із сироваткових білків ефективні також при лікуванні ВІЛ-інфекції, онкологічних i ниркових захворюваннях, а також можуть відігравати роль імуномодуляторів

Так $\alpha$-лактальбумін, який використовують як добавку при лікуванні ниркових захворювань, корегує низький рівень сироваткового альбуміну складу яких входять вуглеводи і сироваткові біло потрапляння у нього білкової іжі, всмоктується у Сироваткові білки представляють собою
амінокислот

лолобіну у крові.

Лактоферрин, який входить до складу лків, застосовують при зниженому . Капа-казеінглікомакропептид, отриманий із виробництві продуктів і напої для людей, я страждають на фенілкетонурію. Це єдиний відомій мінокислот, у тому числі й фенілаланін. технологія впровадження його у виробництво харчових родуктів відпрацьована і реалізована [2]. білків (КДСБ). Ше сухий провукт. Ві сироваткових 1984 р. Синглер, Шоі Ямамото i Джозеф Лателла подали Simplesse $\epsilon$ вторинним могочним продуктом, отриманим із яєчного порошку i/aбо конщентрату молочної сироватки в процесі мікрогранулювання. Simplesse у 3 рази менша. Simplesse-100 не витримує нагрівання більше $100^{\circ} \mathrm{C}$ і не може бути використаним для смаження

Склад та харчова цінність Simplesse-100 не відрізняеться від звичайного концентрату сироваткового білка. Він легко диспергуеться швидко розчиняеться без використання спеціального обладнання або технологій. Simplesse-100 додається до рецептурної суміші за

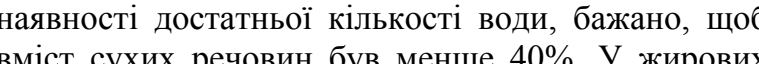
системах речовин був менше 40\%. У жирових гідатован у воднй фaзi

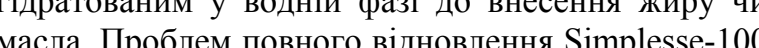
у розбавлених жирових емульсіях, таких як молоко

Застосування коншентрату денатурованих сироваткових білків у вироб̆ництві кулінарно продукції сприяє рівномірному розподілу вологи в емульсійних системах $\mathrm{i}$ забезпечує еластичну структуру [4].

До перспективних напрямів удосконаленн фунц іольно-ехнологічих властивостей біл вудносль також медоди глікозиловання алактальбуміна, $\beta$-лактоглобуліна з використанням гелеутворення [6].

В Росії захищено ряд дисертацій з розробки технологій молочних продуктів зі зниженою сухого мікропартикуляту у Simplesse-100. сирної сироватки, можна використовувати при

Із літературних джерел відомо, що на Захо

Найбільш популярним білковим імітатором жиру на поточній час $\epsilon$ Simplesse-100 отриманий на заявку в патентне бюро США на Simplesse. У порівнянні 3 справжнім жиром калорійність або вершки, не виникає [3]. лактози 1 декстринів [5], а також холодног 


\section{Основна частина}

На потужних підприємствах з виготовлення мікропартикуляту 3 концентрату сироваткових білків, у технологічному процесі застосовується $\begin{array}{lll}\text { дороге } & \text { енергосмне } & \text { обладнання } \\ \text { ультрафільтраційні } & \text { установки, } & \text { плунжерн }\end{array}$ гомогенізатори, вакуум випарні установки та розпилювальні сушильні установки. Для виробництва мікропартикуляту в умовах малих підприємств пропонується модифікувати цю гехнологію і адаптувати іiі до умов виробництва закладах ресторанного господарства.

13 концентрату сироваткових білків пропонусться виробництво мікропартикуляту імітатора жиру. В основу мікропартикуляціі нокладено можливість сироваткового білка

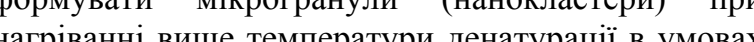
сильного зсуву [8].

оримати з піл сироваткових білків можна ультрафільтрації, а в умовах ресторанного господарства методом відварювання (теплова денатуращія), після вілділення жиру і казеїнового пилу [9].

При нагріві колоїдної системи термічно коагульованих білків, молекули із яких вони утворюються, денатурують (розвертаються), потім починають збиратися в одне ціле. Заміст утворення просторовоі драглеутворюючоі сітк коагульованого білка, білки мікропартикуляту утворюють мікрочастинки 1 ніколи не утворюють гелю. Цей процес утворення молекул можна порівняти 3 процесом «намотування макаронів на вилку».

У процесі отримання мікропартикуляту озинт молекули білка денатурують Завдяки шьому мікрочастинки представпяють собою дуже стабільну форму сироваткового білка яка уже не в змозі агломеруватися або желюватися при нагріванні. Продукт зберігає свої функціональні властивості в умовах високих

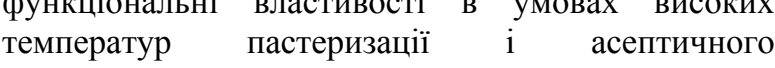
виробництв

Процес молекулярної агрегації починається 3 димерів, 1 при подальшому нагріванні може продовжуватися до тих пір, поки всі молекули не об'єднаються. Однак, ця мимовільна тенденція до агрегаціі може бути припинена в нанометричних границях шляхом прикладення зусиль зсуву доса

На кафедрі технологіі ресторанного

мікропартикулят методом відварювання

Харчова науга і технотогія сироваткових білків та створенням сильного механічного зсуву диспергатором за таких технологічних режимів:

тем- ратуа відваровання сироваткового охолодження і відстоювання білків 1 год. пература $20-25^{\circ} \mathrm{C}$;

- відділення пермеату від сироваткового білка жуванням;

фільтруван концентрату білка методом - ураня,

промивання білка водою - триразове, для вілгіленна коншентрату білка метоло

фільтрування;

- отримання концентрату сироваткового білка 3 совою часткою сухих речовин $24 \%$; мікропартикулювання концентрату дією диспергатора 3 частотою обертання 30000$40000 \mathrm{xB}^{-1}[10$

В результаті мікропартикулювання отримуємо частини біла розміром менше 2 мкм, які надають продукту маслянисту та мастку консистенцію. Частини розміри яких перевищують 2 мкм, надають продукту борошняний присмак та консистенцію.

Для того, щоб упевнитись в ідентичності мікропартикуляту, отриманого за розробленою

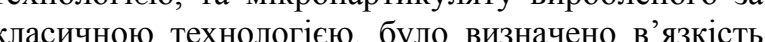
отриманого продукту. Дослідження реологічни властивостей ротаційному віскозиметрі Реотест-2. Він дозволяе визначити динамічну (ефективну) структурну в'язкість в межах від $10^{-2}$ до $10^{4}$ Па с, при визначених швидкостях деформації від 0,2 до $1,3 \cdot 10^{3} \mathrm{c}^{-1}$ в інтервалі температур від - 30 до $150^{\circ} \mathrm{C}$. „Реотест” має набір циліндрів призначених для вимірювання систем з різною в'язкістю. Перемикач діапазону динамометра дозволяс по вибору встановити діапазон напруження зсуву $\left(\begin{array}{llllll}\tau 1 & 1 & 1\end{array}\right)$ відношенням між ними рівним 1:10. Така можливість забезпечує вимірювання напруження зсуву у широкому інтервалі без заміни вимурювального пристрою. Перед вимірюванням
внутрішній циліндр закріплювали на осі внутрішній циліндр
вимірювального валу.

Наважку досліджуваного матеріалу зважували жилер вагах, розмішували в зовнішній віскозиметра i закріплювали шляхом повороту засобу для затискання. Обидва циліндри розміщували у двостінну термостастатичну ємність і термостатували 30 хв при $20^{\circ} \mathrm{C}$.

Далі включали в мережу вимірювальний пристрій. У матеріалах зі структурною в'язкістю
вимірювали залежність між напруженням зсуву і швидкістю зсуву для того, щоб охарактеризувати досліджуваний мікропартикулят 3 точки зору його реологічних властивостей. Вимірювання починали при малих значеннях швидкості зсуву відраховували показання величини $\alpha$ на індикаторному пристрої, яка пропорційна дотичному напруженню. Значен

напруження знаходили за формулою: $\tau=Z \cdot \alpha$,
суву, $10^{-1}$ Па

де $\tau$ - напруження зсуву, $10^{-1}$ Па;
$\mathrm{Z}$ - постійна циліндра, $10^{-1}$ поділу шкали;

$Z$ - постійна цилінду, 10 пділу шкали; пристрої: поділ шкали.

Значення динамічно формулою:

де п - динамічна в язкість, Па с;

ү пвидкість деформації, $\mathrm{c}^{-1}$ (табличне $\begin{array}{ccc}\text { Для характеристики } & \text { структури } \\ \text { мікропартикуляту будували реограму залежності }\end{array}$ $\begin{array}{lrr}\text { Для характеристики } & \text { структури } \\ \text { мікропартикуляту будували реограму залежності }\end{array}$ «динамічна в'язкість - дотичне напруження Ресь визначення в язкості становить $\pm 5 \%$. Реограма відображає залежність швидкост деформації від напруження зсуву (найбіль важливий показник властивостей матеріалу) Вивчення реограми дає змогу віднести даний реалогічних тіл (рис, 1). Дог чозрахунків процесі плинності в ньому продукті можна застосовувати рівняння Бінгама:

$$
\eta=(\tau / \gamma) \cdot 100
$$

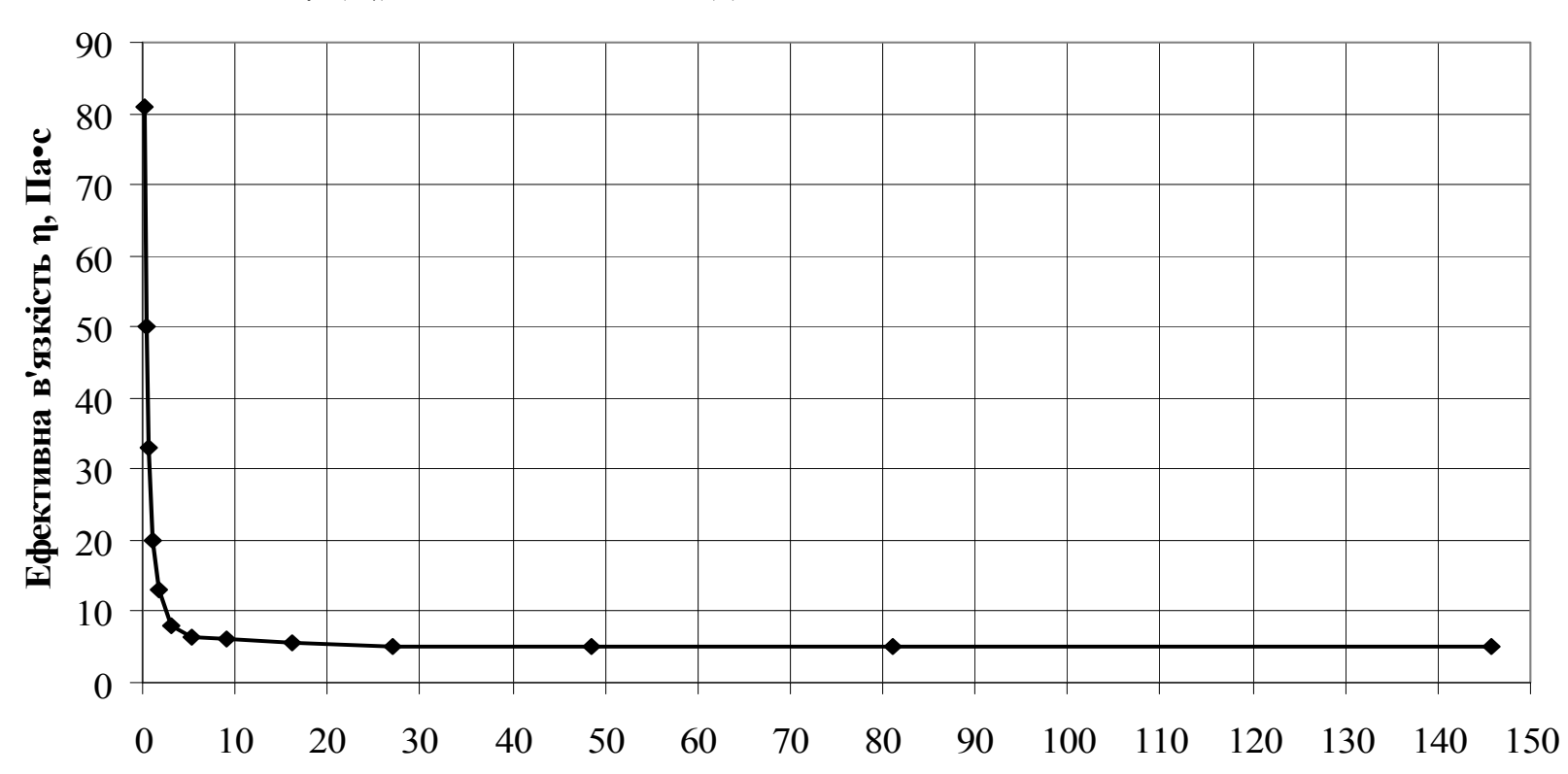

Швидкість зсуву $\gamma, \mathrm{c}^{-1}$

Рис 1. Крива плинності мікропартикуляту отриманогоз конщен та масовою часткою сухих речовин $24 \%$

Із вище наведеного графіка видно, що має місце відновлених зв'язків, що залежать від швидкост нелінійна залежніс, зразо мас спйу струкуру, зсуву, та, имовірно, пояснюеться руйнування

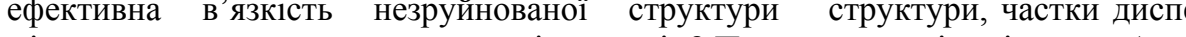
при дотичній напруженості $\gamma=3 \mathrm{c}^{-1}$ (прила А Аналіз отриманих результатів показав, що 3 підвищенням швидкості зсуву при температурі

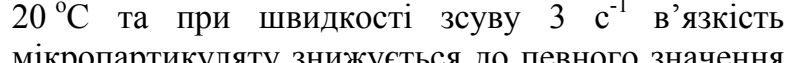
мікропартикуляту знижуеться до певного значення залишасться постійною, не затежно швидкості зсуву. На наведеному графіку умовно виділяються дві ділянки, шо характеризуються зниженням ефективної в'язкості та виходом на постійні значення. Така реологічна поведінка обумовлена співвідношенням зруйнованих та

\section{Висновки}

За своїми реологічними властивостями отриманий мікропартикулят відноситься до певдопластичного матеріалу i ідентичний

Таким чином, мікропартикулят сироваткових білків можна використовувати для повної або частковог заміни жиру у різноманинних продуктах харчування. кумінарних виробах, майонезі, кондитерських і хлібобулочних виробах, молочних речовин $24 \%$ [11]. 
продуктах. Застосування нового імітатора жиру має такі зниження собівартість готового продукту; переваги:

- пдвищення ефективності і екологічнос

переробки молочних сировинних ресурсів;

- збільшення виходу готової продукціі;

- підсилення масткоі консистенці

поліпшення текстури; продукті;

\section{Список літератури}

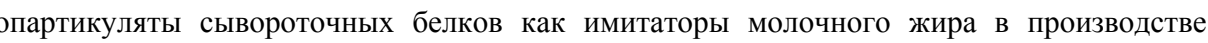
продуктов питания/ Е.И. Меул

Fioris, R Hydrolysis of whey proteins: opportunities for new functionalities [Text]/Rene Floris//Proceedings of the $5^{\text {ih }}$ International Whey Conference/ - Paris, France, 2008

Singer N.S., Moser R.H. Microparticulated proteins as fat substitutes. Low Calorie Foods Handbook: Altschul A.M., Ed.,

Aryana, K.J. Effect of commercial fat replacers on the microstructure of low-fat Cheddar cheese [Text]/K.J. Aryana, Z.U,
Hague//Intern.J. of Food Science \& Technology. - 2001. - Vol. 36. - № 2. - P. 169-177. DOI: 10:1046/j.13652621.2001.00446.x

5. A.C. Alting, R.W. Visschers [Text]/Proceedings of the $4^{\text {ih }}$ International Whey Conference, Chicago, USA, 2005. Chicago: American Dairy Products Institute, 2006. - 387 p. DOI: 10.10121/j034753.r

6. Anema, E. Lowe, K Higgs, Y. Hemar, D. [Text]/Proceedings of the $4^{\text {th }}$ International Whey Conference, Chicago, USA,
2005. - Chicago: American Dairy Products Institute, 2006. - 397 p. DOI: 10.1111/j.1471-0307. 2005 00207. 397 p. DOF 10.1111 j.1471-0307.2005.00207.

иолочно-белковых продуктов: дис. канд. техн. наук: 05.18 .04 /С.В.Манылов. - Кемерово: Кемеровский технологический институт пищевой промышленности, 2009.)

8. Храмцов А.Г. Феномен молочной сыворотки / А.Г. Храмцов. - СПб.: Профессия, 2011. - С. 804.

Дидух Г.В., Пивобезалкогольные напитки на основе ионитной молочной сыворотки/ Г.В. Дидух, А.В. Шалыгин,

корисну модель 86713 Украӥна, МПК А23С 13/00(2013.01). - №2013 08048; заявл. 25.В. Ламп13; опуба // Патент на Бюл. № 1 .

11. Кузнецов О.А., Волошин Е.В., Сагитов Р.Ф. Реология пищевых масс: Учебное пособие. - Оренбург: ГОУ ОГУ,
2005. - С. 106 .

УДК 663.22:547.96

\section{ОПТИМАЛЬНЫЕ МЕТОДЫ ОЦЕНКИ БЕЛКОВЫХ}

ПОМУТНЕНИЙ ИГРИСТЫХ ВИН

С. С. Древова, аспирант

svetik_shum@mail.ru
кафедра технологии вина и энологии*

Л.С. Гураль, кандидат технических наук, доцент
loris shum@ukr.net

кафедра пищевой химии*

*Одесская национальная академия пищевых технологий ул. Канатная, 112, г. Одесса, Украина, 65039
Д.П.Ткаченко, канидат технических наук office@oswc.com.ua

заместитель председателя правления по производству кий завод шампанских вин»

Анотація. Колоїдні помутніння для білих ігристих вин $є$ найбільш характерними, яких важко позбавитись. Порушення рівноважного стану колоїдних компонентів у системі під дією зовнішніх факторів (температура,
освітлення, вібрація тощо) призводить до формування великих частинок, і, як наслідок, появи помутніння 3

утворенням осаду. Такі зміни в шампанських виноматеріалах обумовлено присутністю в них високомолекулярних речовин виноградного і дріжджового походження (білки, полісахариди, фенольні речовини). В теперішній час існус широкий арсенал тестів для прогнозування білкових помупнінь, які у виноробній пракииці широко застосовуються дыя теплових, комбі́і Представлено результати порівняльної ошінки ефективності виявлення протеїнів у білих ігристих винах. З’ясовано, шо показники мутності досліджуваних зразків надають різну інформацію про білки за кожною групою тесті Встановлено, що теплові тести $\epsilon$ малоінформативними та дають лише уявлення про термолабільні протеїни. Групі теплових танінових тестів притаманний найбільш високий рівень кореляції між величинами значень за тестом гарантійним терміном зберігання продукції. Використання тестів, які містять срия

Аннотация. Коллоидные помутнения являются наиболее частыми и трудноустранимыми в белых игристых винах. Нарушение равновесного состояния компонентов коллоидной природы под действием внешних факторов (температура, освещение, вибрация и т.д) приводит к формированию крупных частиц, развитию помутнения образованию осадка. Эии изменения обусловлены прису ферим в шампансих виноматериалах высокомолекулярных сушествует широкий арсенал тестов прогнозирования белковых помутнений, которые в винодельческой практике широко используются для определения стабильности игристых вин. В статье проведена сравнительн характеристика, представленных в отечественной и зарубежной литературе, тепловых, комбинированных химических тестов, а также инструментальных методов определения белкового касса. Представлены результаты сравнительной оценки эффективности обнаружения протеинов в белых игристых винах. Показано, что значения мутносли солй тепловые тесты являю сроком хранения значениями мутности и стабильностью игристых вин.

Ключевьл слова: белковые помутнения, протеины, тесты, нагревание, стабильность вин, игристые вина.

\section{Введение}

Многие потребители, покупая в магазинах шампанские и игристые вина, обращают внимание на внешнее оформление и прозрачность напитка. Наличие помутнений или осадка в бутылке свидетельствует о потере потребительских свойств и несоответствии качественных показателей готовой продукции нормативной документации. Такая продукция изымается из торговой сети и возвращается производителю. Данная проблема приводит К снижению рейтинга продаж соответствующей торговой марки среди игристых вин и шампанского Украины. Маркетинговые вин свигетелствют о повнени требовний потребителей при покупке к визуальныи (прозрачности) и органолептическим поқазателям винопродукции. Следовательно, для повышения конкурентной способности на внутреннем и внешнем рынке винодельческие предприятия Украины должны гарантировать не только высокие ароматические и вкусовые качества напитка, но и обеспечить его стабидын коз различным видам помутнений.

Постановка проблемы и литературный обзор игристых вин, виноделы сталкиваются с коллоидными помутнениями, обусловленными наличием комплекса биополимеров, состоящего из белков, фенольных веществ, полисахаридов, ионо

Харчова наука і технологія
По статистике, основной причиной помутнений Но статис комплекса агротехнических условий, технологических приемов переработки винограда методов осветления и стабилизации сусла и виноматериалов [1]. Обогащение шампанских веществами белковой природы и 作 . продуктов лизиса дрожжей

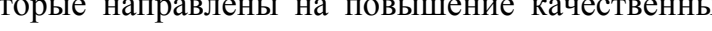
показателей игристых вич

Основные работы по исследованию саабильности белых вин и разработки тестов

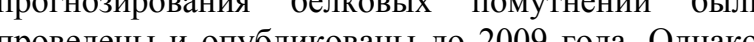

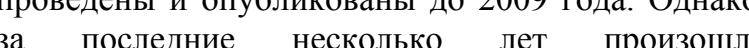
фффективное - технико-техногогическо перевооружение отрасли. Внедрение современного гехнодогического оборудования способствовало резкому снижению содержания тяжелых металлов в виноматериалах, участвующих в процессах лестабилизации коллоидной системы игристых

На основании механизма возникновения белковых помутнений с участием всех ков коллоидной природы многие авторы ремоменду розлизостойкость вин определяв с с 